IWONA RADZISZEWSKA

\title{
Język ksiąg religijnych Tatarów litewsko-polskich, funkcjonujących w środowisku muzułmanów polskich
}

Słowa klucze: Tatarzy, rękopisy, język, alfabet arabski

Środowisko muzułmanów żyjących w Polsce można podzielić na kilka grup. Jeden z podziałów zaproponował Marek Kubicki na łamach „Tygodnika Powszechnego". Wyróżnił on cztery grupy muzułmanów: najmłodszą i najliczniejszą stanowią muzułmanie napływowi, mieszkający w Polsce zaledwie kilka lub kilkanaście lat (uchodźcy z krajów muzułmańskich), drugą i najstarszą, liczącą kilka tysięcy osób grupę tworzą Tatarzy dawnego Wielkiego Księstwa Litewskiego. Kolejną grupę stanowią również muzułmanie napływowi, ale zasymilowani i mieszkający w Polsce nawet od kilkudziesięciu lat, ostatnią natomiast tworzą neofici, czyli ci, którzy niedawno przyjęli islam (za: Kubicki 2006: 4). Podział ten można zredukować do trzech grup o całkowicie różnym charakterze i wśród muzułmanów zamieszkujących Polskę wyróżnić: Tatarów litewsko-polskich jako najstarszą grupę muzułmanów, historycznie związaną z Rzeczpospolitą, następnie grupę muzułmanów napływowych, oraz najmłodszą i najmniejszą grupę konwertytów.

W niniejszym artykule pragnę skupić uwagę na środowisku muzułmanów polskich, które ograniczę do Tatarów litewsko-polskich (zwanych też polskimi). Ograniczenie to jest odwołaniem do tradycyjnego obrazu polskiego środowiska muzułmańskiego jeszcze sprzed kilku, czy kilkunastu lat, gdy było ono kojarzo- 
ne głównie z ludnością tatarską zamieszkującą w Wielkim Księstwie Litewskim od wieków. Podobny obraz tego środowiska przedstawia m.in. historyk Ali Miśkiewicz, który jako współautor książki Tatarzy Słowiańszczyzna obłaskawieni, pisze: „Muzułmanie dzisiejsi często określają siebie mianem muzułmanów polskich, do czego z racji historycznych nie powinni mieć prawa, gdyż nazwę tę odnoszono do niedawna jedynie do społeczności tatarskiej” (Miśkiewicz, Kamocki 2004: 165).

Mówiąc o społeczności tatarskiej, nie można odnieść się do konkretnego języka konkretnej mniejszości językowej, ponieważ Tatarzy litewsko-polscy nie tworzą takiej mniejszości. Zalicza się ich, choć klasyfikacja ta nie jest sprecyzowana, do mniejszości etnicznych, a także regionalnych, związanych z konkretnym terenem. Określenia te wydają się trafne ze względu na ścisłe powiązanie, jak też kojarzenie Tatarów litewsko-polskich z ziemiami głównie północno-wschodniej Polski. Jeszcze trafniejsze wydaje się określenie ,grupa etnokonfesjonalna"1, ze względu na zaznaczoną w nazwie istotną rolę łączącego tę grupę wyznania, które pozostaje ważnym, jeśli nie najważniejszym spoiwem społeczności i czynnikiem formującym poczucie tożsamości oraz świadomość etniczną jej członków.

Nawiązując do całościowego obrazu i podziału środowiska muzułmańskiego oraz istotnej roli wiary w każdej z wymienionych grup, można powiedzieć, że językiem, do którego można się tu odwołać, jest język polski i/lub język białoruski ze względu na funkcjonowanie wszystkich wymienionych grup obecnie na terenie Polski i Białorusi, a dawniej Wielkiego Księstwa Litewskiego, jak i język arabski (także turecki), ze względu na pochodzenie grupy oraz wyznawaną religię. Taka sytuacja językowa sprawia, że przedstawione grupy społeczeństwa muzułmańskiego mają pewne punkty wspólne także na płaszczyźnie językowej.

Powracając do sytuacji wewnątrz społeczności tatarskiej, języki: arabski (turecki, elementy perskiego), białoruski i polski, od dawna współistnieją w piśmiennictwie religijnym Tatarów Wielkiego Księstwa Litewskiego. Języki słowiańskie przenikały do sfery życia codziennego polskich muzułmanów, a języki etniczne oraz liturgiczny arabski stawały się stopniowo językami martwymi w przypadku tejże grupy. W powstałych księgach religijnych Tatarów litewsko-polskich odpowiednio zmodyfikowany alfabet arabski kryje każdy z ww. języków.

1 Por. Wicherkiewicz [http://www.wtk.poznan.pl/Orw/Archiwum/20001019/Wicherkiewicz.html]. 
Powstałe na ziemiach Wielkiego Księstwa Litewskiego rękopiśmienne księgi tatarskie mają swój początek w drugiej połowie XVI wieku, a najstarsze znane rękopisy datuje się na XVII wiek ${ }^{2}$, co ustalono w badaniach nad wspomnianymi rękopisami.

Był to okres ostatniej fazy asymilacji językowej Tatarów, która, z powodu wspomnianego już zaniku znajomości języków orientalnych, groziła zupełnym zerwaniem z tradycją i religią przodków. Sytuacja taka stała się bodźcem do stworzenia literatury religijnej w przejętych przez społeczność tatarską językach słowiańskich. Pierwszy raz o polsko-tatarskich księgach w języku „Lahów niewiernych", a zapisanych w całości alfabetem arabskim wspomina turecki historyk Ibrahim Peczewi już w latach dwudziestych XVII wieku (Drozd 1999: 21-22).

Wpływem słowiańskiego otoczenia na społeczność tatarska, który najwyraźniej widać na przykładzie rękopiśmiennych ksiąg, jest wprowadzenie do tychże ksiag religijnych języków słowiańskich. W obrządku religijnym, który pozostał jedynym elementem łączącym muzułmanów polskich z kulturą krajów arabskich, pojawił się język obcy tej kulturze, z jednej strony oddalający Tatarów od oryginalnej kultury islamu, z drugiej pozwalający zachować ją i krzewić na nowym gruncie. Sam obrządek przekazywany w treści ksiąg pozostał w dużej mierze niezmieniony. Język rękopisów tatarskich można nazwać narzędziem kształtującym i organizującym świadomość religijną tej społeczności.

Piśmiennictwo Tatarów litewsko-polskich obejmuje kilka rodzajów ksiąg. Są to: chamaity (modlitewniki), rękopiśmienne kopie Koranu, kitaby (zbiory opowieści, legend i zwyczajów muzułmańskich), tedżwidy (podręczniki do czytania Koranu), tefsiry/tafsiry (zawierające objaśnienia do Świętej Księgi w postaci interlinearnego przekładu jej treści na język słowiański). Do rękopisów można też zaliczyć inne, mniejsze formy piśmiennictwa, traktowane jako amulety. Sa to nuski (pełniące funkcję ochronną kartki z wypisaną na nich modlitwą z chamaiłu), hramotki (zwój z modlitwą, który noszony również ma pełnić funkcję ochronną) i daławary (podobny zwój modlitw, aczkolwiek większych rozmiarów, wkładany do grobu ze zmarłym), czy też muhiry (również o charakterze dewocyjno-magicznym, które mają formę plansz z cytatami z Koranu) (Drozd, Dziekan, Majda 2000: 12-16).

2 Zob. m.in.: Cz. Łapicz (1986: 62-64); A. Drozd (1999: 21-22); autorzy ci obszernie argumentują ustalone ramy czasowe w odwołaniu do uwarunkowań historycznych oraz sytuacji społecznej i religijnej Tatarów litewsko-polskich. 
Specyficzny charakter i forma wymienionych ksiąg oraz ich język są wynikiem funkcjonowania społeczności muzułmańskiej w otoczeniu słowiańskim i chrześcijańskim. Przykładem takich ksiąg są chamaity, które są rękopisami najbardziej rozpowszechnionymi wśród Tatarów litewsko-polskich. Pełnią one funkcję modlitewników, brewiarzy i jako takie stanowią zbiór modlitw na różne okazje i święta.

Zarówno zawartość modlitewników, jak i sama nazwa księgi stanowią kompilację kultury muzułmańskiej i wierzeń szamańskich, a częściowo elementu słowiańskiego. Funkcjonujący wśród Tatarów termin chamait pochodzi od arabskiego czasownika hamala (حمل), czyli 'nosić' (Turek 2001: 212-213). W języku arabskim oznaczał też amulet (Drozd, Dziekan, Majda 2000: 13; Kulwicka-Kamińska 2004: 44). Muzułmanie polscy przejęli tę nazwę dla modlitewnika, z którym wierny, podobnie jak z amuletem, nie powinien się rozstawać (Danecki 1997: 81).

Bogatą zawartość modlitewników tatarskich można ująć w następujących punktach $^{3}$ :

- modlitwy arabskie i tureckie,

- objaśnienia i wprowadzenia do tychże modlitw w języku polskim i białoruskim,

- opis rytuałów muzułmańskich - ablucje, nabożeństwa zbiorowe, obrzędy,

- formuły okolicznościowe i teksty dewocyjne,

- kalendarz muzułmański,

- teksty o charakterze magicznym - egzorcyzmy, wróżby, zestawienia dni feralnych i szczęśliwych, formuły na leczenie chorób, tłumaczenia snów itp.

W zależności od zawartości, konkretne modlitewniki służyły wiernym, imamom, wróżbiarzom lub znachorom.

W każdym modlitewniku tatarskim można wyodrębnić część słowiańską i orientalną, które przeplatają się ze sobą, a jednocześnie każdy z języków przedstawia treści innego rodzaju. Język arabski zarezerwowany jest dla pojęć religijnych oraz modlitw, których treść pozostawiono w oryginale, natomiast języki słowiańskie służą do objaśniania tej treści, wyjaśnienia znaczenia, celu i okoliczności odmawiania danej modlitwy. Podział taki nasuwa myśl, że języki słowiańskie stały się jedynie praktycznym narzędziem, służącym do udzielania

3 Zawartość wymieniona na podstawie: A. Drozd, M. M. Dziekan, T. Majda (2000: 13); J. Szynkiewicz (1935: 139). 
wskazówek wiernemu nieznającemu języka arabskiego, ale nie przeszły do sfery sacrum ${ }^{4}$.

Oprócz treści podstawowej, tatarskie modlitewniki były opatrywane przez właścicieli zapiskami umieszczanymi na marginesach lub ostatnich, pustych stronach księgi. Zapiski te dotyczyły ważnych wydarzeń lub osób związanych z rodziną, czy też duchowym i świeckim życiem właściciela chamaiłu. Stanowiły więc jednocześnie swoisty notatnik, pamiętnik rodzinny, przekazujący przyszłym pokoleniom informacje dotyczące historii rodu. Notatki były sporządzane w języku polskim lub białoruskim i, zależnie od tego, posługiwano się tu łacinką lub cyrylica.

Treść właściwa modlitewnika łączy praktycznie pięć języków: arabskie i tureckie modlitwy, z włączonymi w nią także perskimi pojęciami i znakami, objaśniane są w języku polskim i białoruskim, a ściślej przy użyciu północno-wschodniej polszczyzny kresowej, charakterystycznej dla pogranicza zamieszkałego przez Tatarów litewsko-polskich i odbijającej specyfikę terenów stanowiących mieszankę narodowości i kultur. Wszystko to, a więc fragmenty polsko-białoruskie i orientalne, zapisywano alfabetem arabskim z wykorzystaniem pojedynczych liter $\mathrm{z}$ alfabetu tureckiego i perskiego oraz oryginalnych, nowo utworzonych grafemów, które Tatarzy litewsko-polscy wprowadzili dla oddania dźwięków mowy słowiańskiej. Alfabet arabski, w celu stworzenia tejże literatury, musiał być bowiem zmodyfikowany dla wyrażenia cech języków słowiańskich.

Język modlitewników oraz problemy, z jakimi stykali się polscy muzułmanie podczas tworzenia ksiąg religijnych, najlepiej zilustruje kilkuwersowy fragment tekstu pochodzący z chamaiłu. Jest to modlitewnik z 1910 roku, przepisywany przez Tamerlana Krynickiego (informacja z kolofonu), będący obecnie prywatną własnością Heleny Jakubowskiej z Sokółki.

${ }^{4}$ Opisy polsko-białoruskie były (są) jednak czytane i powtarzane przez imamów podczas nabożeństwa, a więc wprowadzane do liturgii, dlatego można by mówić o sakralizacji języków słowiańskich. 


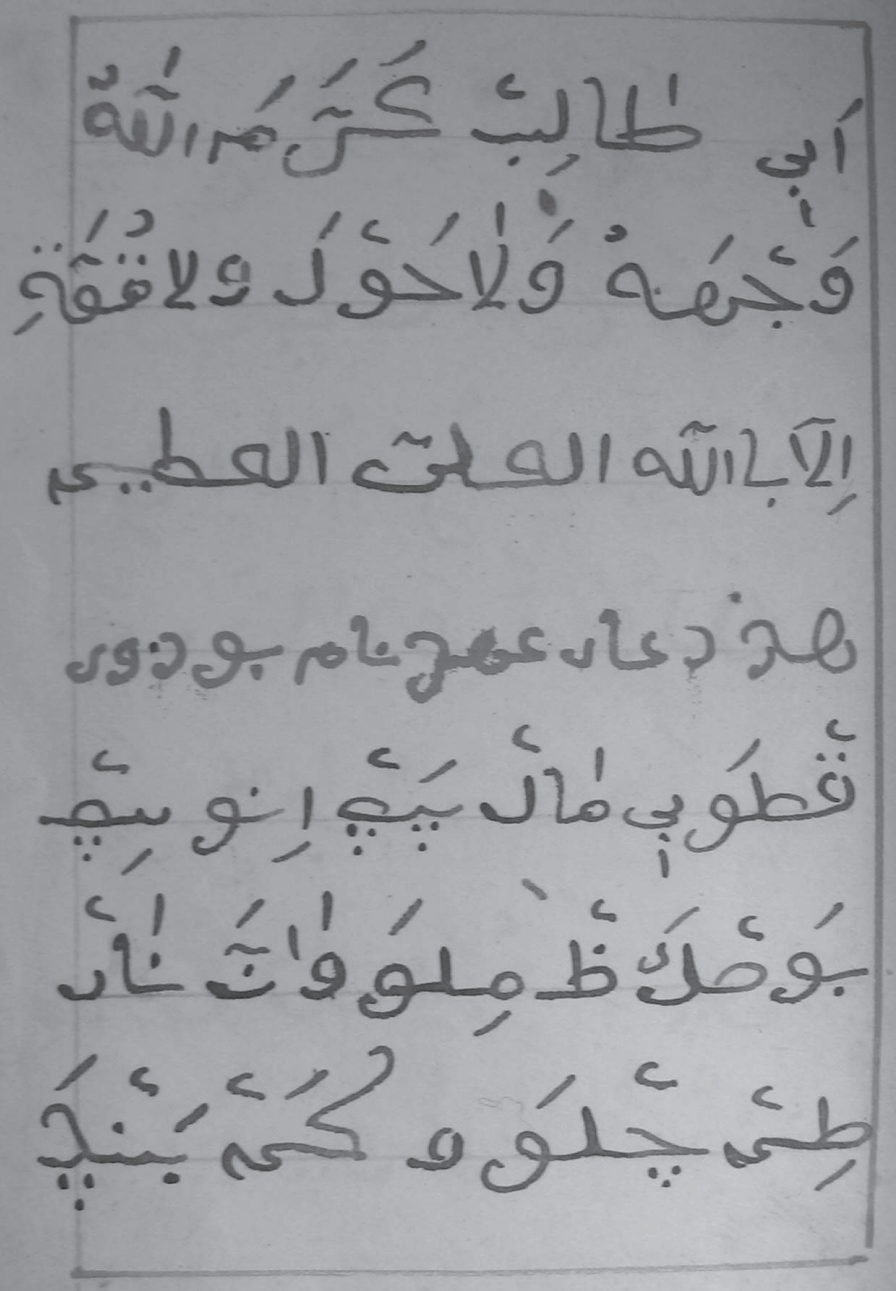

Fotografia 1. Strona z chamaiłu Tamerlana Krynickiego (źródło: opracowanie własne na podstawie udostępnionego modlitewnika) 
Transliteracja części słowiańskiej tekstu:

$1-4$ w. $^{5}$ tekst arabski

5 w. kto bí mal pec i n[o]s'ic

6 w. bosk'e żmilovánne nad

7 w. tim člov[e]k'em benze

Już na podstawie niewielkiego fragmentu tekstu można dostrzec podstawowe cechy zapisu graficznego oraz języka tego typu zabytku. Przy wykorzystaniu spółgłoskowego alfabetu języka arabskiego Tatarzy musieli rozwiązać m.in. problem oddania w tekście (i mowie) samogłosek. W polskich i białoruskich tekstach modlitewników tatarskich zaznaczane są one za pomocą trzech istniejących już w alfabecie arabskim znaków wokalizacyjnych, nad lub pod literami, które jednak okazały się niewystarczające dla oddania wszystkich samogłosek występujących w językach słowiańskich. Na przykład samogłoski [y] oraz [i] oddaje się za pomocą tego samego znaku, a mianowicie za pomocą $k a$ sry, znaku wokalizacyjnego w postaci ukośnej kreski umieszczanej pod litera, oznaczającego w alfabecie arabskim $i$ krótkie. Odczytanie tego znaku jako [y] lub [i] będzie więc zależało od kontekstu, leksemu, w którym się znajduje, oraz

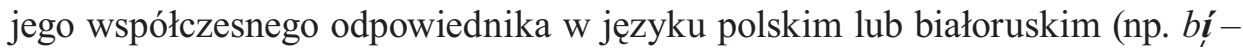
'by', tim - 'tym', n[o]s'ic - 'nosić'). Jednak konsekwentna transliteracja wymaga ujednolicenia zapisu znaku, stąd zawsze odpowiada on w transliteracji literze [i], jako że w alfabecie arabskim istnieje jej odpowiednik, [y] natomiast nie istnieje. $Z$ kolei typowe dla polszczyzny nosówki oddaje się za pomocą połączenia samogłoski ustnej i spółgłoski nosowej, gdy występują one w śródgłosie (benze), natomiast na końcu wyrazu lub w śródgłosie przed literą $l$ zapisywane są zgodnie z wymowa jako [e] lub [o] (Łapicz 1986: 120-123).

W przytoczonym fragmencie widać też, że kasra nie wszędzie ma identyczny kształt ukośnej kreski, ale może być postawiona pionowo. W takiej formie pojawia się w połączeniu z literą $s$ (ar. 'ja', samodzielnie oznaczająca j) przeważnie w pozycji wygłosowej (Łapicz 1986: 119). We fragmencie tekstu znaki diakrytyczne obu liter: $ى$ oraz $($ (b) zeszły się pod jednym znakiem, co można uznać za specyfikę stylu pisania kopisty.

Znaki wzorowane na alfabecie arabskim, moga przybierać również nieco inne, zmienione lub uproszczone kształty. Znak sukun, oznaczający brak wokalizacji, w języku arabskim ma kształt zamkniętego okręgu (o), w alfabecie

5 w. - oznacza tu wiersz. 
zmodyfikowanym przez Tatarów może być oznaczany półokręgiem skierowanym otwartą stroną w prawo, umieszczanym nad literą. W takiej też formie występuje w cytowanym fragmencie rękopisu.

Omawiane teksty nie były też wolne od błędów i nieścisłości, co widać np. w wyrazie ćlov[e]k'em, gdzie przy grafemie $v$ brakuje fathy, znaku wokalizacyjnego w postaci ukośnej kreski nad literą, wprowadzającego głoskę [e] (litera w nawiasie została dodana w transliteracji). Brak znaku diakrytycznego widać również w wyrazie $n[o] s$ 'ic, gdzie samogłoskę [o] oddano samym wawem (و), tymczasem samogłosce [o] odpowiada połączenie wawu z fatha, jak w wyrazie kto.

Przemieszanie języków słowiańskich widać z kolei na przykładzie wyrazu pec. Aby odczytać jego znaczenie, można pokusić się o interpretację jego wymowy. Ze względu na zmiękczającą samogłoskę [e], był wymawiany prawdopodobnie miękko jako pieć, czyli nawiązując znów do dawnej polszczyzny: 'śpiewać', czasownika występującego dawniej w formie piać (Reczek 1968: 862). Chodzi tu o odśpiewanie modlitwy, a formę infinitivu pieć, a nie piać, można odnieść do staropolskiego określenia śpiewu jako pienie (Reczek 1968: 320), realizowaną we wschodniosłowiańskiej formie fonetycznej (por. rosyjskie nemb - 'śpiewać'). Jeżeli chodzi o interpretację wygłosowego [c] jako głoski miękkiej w czasowniku transliterowanym jako pec, jest to uzasadnione, jeśli porównamy tę formę do polskiego śpiewać, ponownie do rosyjskiego nemb, a także do białoruskiego сьпяваиь oraz odniesiemy się do cech polszczyzny kresowej, która pojawia się w omawianych rękopisach - w każdym wypadku głoska [c] jest w wygłosie zmiękczona.

W mieszance językowej, jaką prezentują modlitewniki tatarskie, można (nie zawsze) wskazać cechy, które precyzuja język rękopisu lub jego fragmentu, a ściślej jego słowiańskiej części. Obecny w transliterowanym wyżej fragmencie leksem benze, zawiera typową dla polszczyzny nosówki ę realizowaną tu jako en, a więc przez połączenie: samogłoska ustna + spółgłoska nosowa (Łapicz 1986: 85), w wyrazie $n[o] s^{\prime} i c$ brak z kolei akania, a w leksemie člov[e]k'em nie występuje ani akanie, ani pełnogłos, co w sumie może świadczyć o polskości fragmentu.

Przytoczony niewielki fragment tekstu wskazuje na łączenie elementów orientalnych i słowiańskich na płaszczyźnie językowej. Ta oryginalna kompilacja pozwoliła Tatarom zachować tradycję przodków, a przy okazji stworzyć własną, oryginalną literaturę religijną, w języku, który stał się ich językiem narodowym. Jednocześnie odnosi się ona wciąż do religii ich ojców. 
Wprowadzenie języka słowiańskiego do praktyk religijnych było odpowiedzią na asymilację językową społeczności tatarskiej. W codziennej mowie Tatarów pozostały jednak wyrazy pochodzenia arabskiego czy tureckiego, związane $\mathrm{z}$ obrządkiem i rytuałami islamu. Wiele $\mathrm{z}$ tych terminów zostało również spolszczonych, a ponadto znane były w polszczyźnie od XVI w., czyli wchodziły do słownictwa polskiego wraz z powstaniem literatury religijnej Tatarów litewskopolskich. Są to terminy typu ${ }^{6}$ :

- bajram (tur. 'bayram') - święto

- chadż, chadždž, chedždž (ar. 'hạğğg') - pielgrzymka

- matna, molta, mułta, munła (ar. 'maulā') - muzuůmański duchowny

- mieczeć, mieczet, mesdżyd, mečic (ar. 'masğid') - meczet itp.

Zmiany zachodzące $\mathrm{w}$ funkcjonowaniu społeczności tatarskiej widać również na podstawie ksiagg, które pojawiły się w XX w. Widać je, jeśli weźmie się pod uwagę formę nowych modlitewników, już nie przepisywanych, a drukowanych, w których fragmenty dotyczące sposobu wykonywania obrzędów czy opisu rytuałów całkowicie przetłumaczono na język polski i zapisano łacinką, a modlitwy zapisane w języku arabskim przetransliterowano na alfabet łaciński (pozostawiając czasami, choć nie zawsze, na przeciwległej stronie tekst modlitwy zapisany oryginalnym pismem arabskim). W ten sposób wierni nie znający języka Świętej Księgi ani w piśmie, ani w mowie, mogli się modlić w języku arabskim, powtarzając spisane modlitwy, nie rozumiejąc ich, ale stosując się do wymienionych w modlitewnikach wskazówek ${ }^{7}$.

Na podstawie badań i wywiadów przeprowadzonych w środowisku tatarskim na Podlasiu ${ }^{8}$, mogę potwierdzić, że chamaity posiada wciąż większość rodzin pochodzenia tatarskiego. Najcenniejsze są najstarsze rękopisy, przekazywane w rodzinie z pokolenia na pokolenie, ale Tatarzy dysponują również modlitewnikami stosunkowo nowymi, przepisywanymi ręcznie na podstawie starych ksiąg. Co więcej, nadal powstają nowe księgi, które wychodzą m.in. spod pióra imama sokólskiego Konstantego Szczęsnowicza. Fakt ten świadczy o tym, że tradycja kopiowania ksiąg religijnych nie zanikła i jest nadal pielęgnowana.

${ }^{6}$ Na podstawie: J. Kulwicka-Kamińska (2004).

7 Przykład tego typu modlitewnika: Zbiór modlitw do wykonywania obrzadków azanu, nikiachu, dżenazie i składania ofiary ,,kurban” autorstwa A. Smajkiewicza, wydany w formie kserokopii (Gdańsk 1970).

8 Badania terenowe przeprowadzane w latach 2005-2007 w Bohonikach, Białymstoku, Sokółce i Suchowoli. 
Tatarzy mieszkający w Polsce czują się jej obywatelami, a jednocześnie świadomi są swojej przynależności religijnej. Odzwierciedlają to w pewien sposób język, forma i treść tatarskich ksiagg religijnych, które łączą Słowiańszczyznę z Orientem. Proces asymilacji językowej oraz zmiany w świadomości, które następowały równolegle do tego procesu, nie zagroziły utracie tożsamości religijnej, a wręcz pomogły Tatarom zachować religię przodków. Wciąż przechowywane w rodzinach rękopisy religijne są szansą na zachowanie więzi w społeczności tatarskiej oraz na podtrzymanie tradycji, a tym samym szczególnego charakteru grupy.

\section{Bibliografia}

DANECKI J., 1997, Kultura islamu. Stownik, Warszawa: WSiP.

DrozD A., 1999, Arabskie teksty liturgiczne w przekładzie na język polski XVII wieku, Warszawa: Wydawnictwo Akademickie DIALOG.

Drozd A., Dziekan M. M., MajDa T., 2000, Piśmiennictwo i muhiry Tatarów polsko-litewskich, Warszawa: Res Publica Multiethnica.

KUbicki M., 2006, Nieoczekiwana zamiana miejsc. Polscy muzułmanie w cieniu islamu wahabickiego, Tygodnik Powszechny Nr 37/2006 (2983), s. 4.

Kulwicka-KamińsKa J., 2004, Ksztaltowanie się polskiej terminologii muzutmańskiej, Torun: Towarzystwo Naukowe w Toruniu.

ŁapICz C., 1986, Kitab Tatarów litewsko-polskich. (Paleografia. Grafia. Język), Toruń: Wydawnictwo UMK.

Miśkiewicz A. A., Kамоскі J., 2004, Tatarzy Stowiańszczyznq obłaskawieni, Kraków: Universitas.

Reczeк S., 1968, Podręczny stownik dawnej polszczyzny, Wrocław-Warszawa-Kraków: Ossolineum.

SzynkiEwicz J., 1935, Literatura religijna Tatarów litewskich i jej pochodzenie, Rocznik Tatarski, t. 2, s. 138-144.

TuReK W. P., 2001, Stownik zapożyczeń pochodzenia arabskiego w polszczyźnie, Kraków: Universitas.

Wicherkiewicz T., Tożsamość mniejszości językowych w Rzeczypospolitej Polskiej [online], http://www.wtk.poznan.pl/Orw/Archiwum/20001019/Wicherkiewicz.html, [31.01.2007]. 


\section{Die Sprache der Religionsbücher von litauisch-polnischen Tataren, die in der Gemeinschaft von polnischen Muslimen funktionieren \\ (Zusammenfassung)}

Die litauisch-polnischen Tataren leben seit Jahrhunderten auf polnischem Gebiet und sind seit langem assimiliert. Dennoch bilden sie eine Gruppe, die sich durch ihre muslimische Konfession und durch das Bewusstsein über ihre Herkunft unterscheidet. Sie pflegen den Ahnenglauben. Die Europäisierung (oder konkret Slawisierung) ihres Lebens hat keinen Schwund der mit dem Geistesleben und der Religion verbundenen Tradition bewirkt. Davon zeugt unter anderem, dass die Tataren eigene Religionsbücher besitzen.

Diese handschriftlichen Bücher, die man von Generation zu Generation weitergibt, kann man als eigenartige Hybride bezeichnen, die ähnlich wie ihre Besitzer Elemente der arabischen und slawischen Welt verbinden. Nicht nur im täglichen Leben haben die Tataren nämlich die Sprache ihrer Umgebung übernommen. Auch in diesen Manuskripten kann man die polnische Sprache finden, obwohl sie durch die Verwendung des arabischen Alphabets verborgen ist. Die Form und die Sprache dieser Religionsbücher, die eben das Thema des Referates bilden, spiegeln gleichzeitig den komplizierten Charakter der Gruppe wider. 